\title{
Characteristics of Greenhouse Gas Emission in the Upland Soil Applied with Agricultural Biomass
}

\author{
Woo-Kyun Park*, Gun-Yeob Kim, Sun-Il Lee, Joung-Du Shin, Hee-Young Jang, and Kyu-Ho So \\ National Academy of Agricultural Science, RDA, Wanju 565-851, Korea
}

(Received: October 2 2014, Revised: October 16 2014, Accepted: October 17 2014)

\begin{abstract}
$\mathrm{NH}_{4}-\mathrm{N}$ contents in the soil treated were relatively high in the initial stages, but rapidly decreased at 124 days after treatment. $\mathrm{NO}_{3}-\mathrm{N}$ contents were shown to be opposite patterns of $\mathrm{NH}_{4}-\mathrm{N}$ contents. $\mathrm{CO}_{2}$ emissions in the non-treatment and Carbonized rice hull treatment with application of NPK fertilizers decreased by 43.7 and $21.9 \%$ relative to the non-application of NPK fertilizer plot except $5.4 \%$ increasement in the pig manure compost treatment. $\mathrm{N}_{2} \mathrm{O}$ emissions of the non-application, the Expander rice hull application, and bio-char treatment increased by 90,25 , and $21.4 \%$, respectively, but decreased by $54.2 \%$ in the pig manure compost treatment applied with NPK fertilizers compared with the NPK fertilizer non-application plot.
\end{abstract}

Key words: Greenhouse Gas emission, $\mathrm{CO}_{2}, \mathrm{~N}_{2} \mathrm{O}$, Biomass, Carbonized Rice Hull
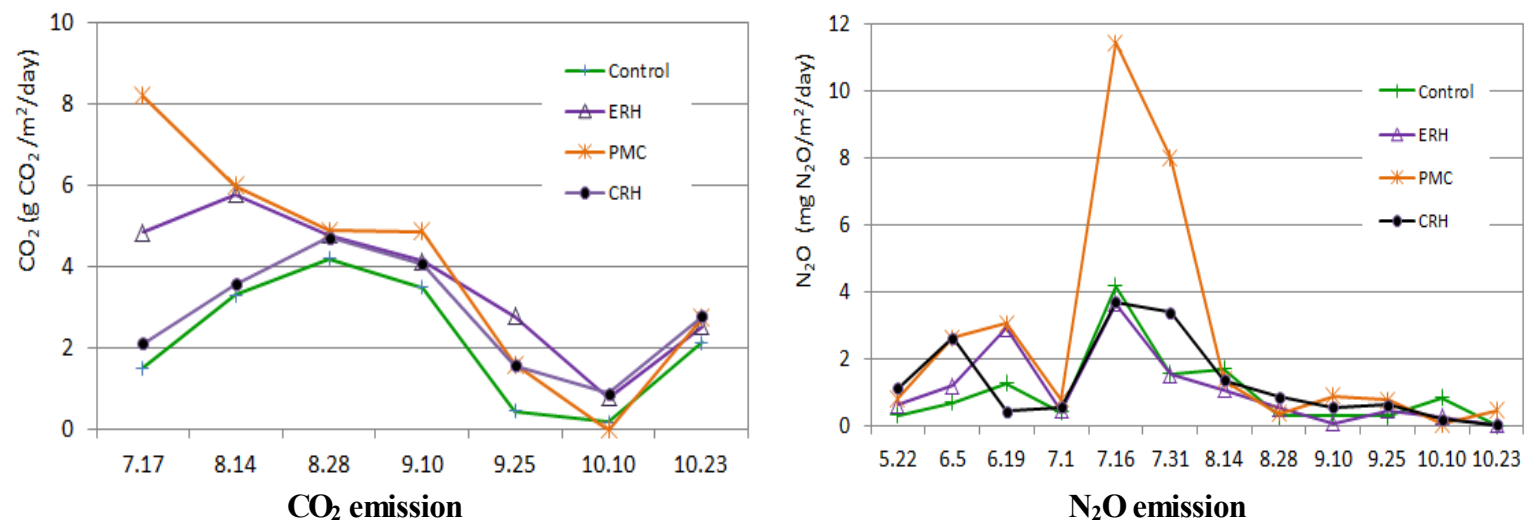

Changes of $\mathrm{CO}_{2}$ and $\mathrm{N}_{2} \mathrm{O}$ emissions by different biomass in upland soils(all flux measurements included). in NPK fertilizer none, ERH : Expander Rice hull, PMC : Pig Manure Compost, CRH : Carbonized Rice hull. 


\section{Introduction}

지구온난화 현상은 전 지구적으로 매우 중요한 문제로 인식되고 있으며, 이산화탄소, 메탄, 아산화질소 등이 많은 영향을 미치는 것으로 알려져 있다 (Scheutz and Kjeldsen, 2004). $\mathrm{CO}_{2}$ 농도는 산업화 이전 $280 \mathrm{ppm}$ 에서 2005년에는 $379 \mathrm{ppm}$ 으로 증가하였고 화석연료의 연소에 의한 배출이 $2 / 3$, 토지사용 변화에 의한 배출이 $1 / 3$ 을 차지하는 것으로 추정되고 있다. 아산화질소 $\left(\mathrm{N}_{2} \mathrm{O}\right)$ 의 경우에도 산업화 이전 보다 약 $18 \%$ 높은 $319 \mathrm{ppb}$ 로 인간 활동으로 인한 농업활동 중 특히 질소를 함유한 비료사용에 의한 영향으로 증가되고 있다 (IPCC, 2007). 토양 미생물이 농경지에 시용된 질소질 비료나 가축분뇨 퇴비를 질산화 과정과 탈질 과정을 거쳐 변환시키는데, 이 과정에서 부산물이나 중간산물로 아산화 질소가 만들어 진다 (Freney, 1997; Singh and Tyagi, 2009). Keren and Johnson (1993)은 밭에서 무경운 재배에 의한 온실가스 배출 감축 효과는 아산화질소 배출이 감소하고, 토양 유기탄소는 증가하는 반면, 경운재배는 아산화질소 배 출이 증가한다고 하였다. $\mathrm{Gu}$ et al. (2009)은 자연 상태에서 배출되는 아산화질소의 26-30\%는 농경지로부터 배출되는 것으로 추정하였다. 또한 농경지로부터 아산화질소 배출에 영 향을 미치는 요인으로는 질소 시비량, 토양 유기물 함량, 토양 산도, 토성, 작물 종류, 양분원의 종류 등이 있다 (Stehfest, 2008)

Firestone and Davidson (1989)은 토양에서 아산화질소 $\left(\mathrm{N}_{2} \mathrm{O}\right)$ 의 배출은 유기물이나 비료 시용을 줄이는 것보다 토 양 중에서 발생하는 질산화 및 탈질 작용 등 생화학적 과정 을 적절히 조절하는 것이 더 큰 효과를 볼 수 있다고 하였 다. 우리나라의 농업분야에서 발생되는 바이오매스의 양은 연간 1,160 만톤으로 추정되고 있으나 자원 순환활용에 대 한 연구가 거의 없는 실정이다 (Park et al., 2011). 바이오 매스는 모든 식물과 동물의 자양분 그리고 가정과 산업체로
부터 발생되는 배출물과 바이오 폐기물을 포함하는 탄소가 풍부한 소재이다 (Deublin and Steinhauser, 2008). 농업에 서 유래된 미 사용 또는 폐기된 바이오매스 잔사는 잠재 에 너지원이나 유기물 공급원으로 유용하나, 이러한 자원을 방 치하거나 소각하게 되면 환경문제와 더불어 온실가스 배출 원이 될 수 있다. 그러나 바이오매스를 공기가 부족한 상태 에서 연소시켜 만든 바이오솣을 토양에 시용하면 아산화질 소의 배출량을 줄일 수 있다는 연구 결과들이 보고되고 있 다 (Yanai et al., 2007).

따라서 본 연구에서는 농업부문의 주요 바이오매스 활용 으로 인한 온실가스 배출을 줄이고자 여러 형태의 바이오매 스를 밭토양 조건에 처리하였고, 온실가스 배출에 영향을 주는 토양의 온도 및 수분 변화와 더불어 바이오매스 처리에 따른 온실가스 $\left(\mathrm{CO}_{2}, \mathrm{~N}_{2} \mathrm{O}\right)$ 배출 특성을 밝히고자 하였다.

\section{Materials and Methods}

본 연구는 바이오매스 처리가 농경지에서 온실가스 배출에 미치는 영향을 살펴보기 위하여 경기도 수원시에 위치한 국립농 업과학원의 시험포장 (위도: $37^{\circ} 25^{\prime} 84.0^{\prime \prime} \mathrm{N}$, 경도: $126^{\circ} 98^{\prime} 81.0^{\prime \prime} \mathrm{E}$ ) 에서 수행하였다. 시험은 밭 포장 조건에서 무저 포트를 설 치하여 실시하였고, 시험토양은 사양질로서 화학적 특성은 Table 1과 같다.

작물생육에 의한 온실가스 배출 영향을 제거하기 위하여 포트상에 작물은 재배하지 않았다. 시험구 면적은 $120 \mathrm{~m}^{2}$ $(15 \times 8 \mathrm{~m})$ 로 하였으며, 시험구 처리는 바이오매스 무처리구, 팽연왕겨 처리구, 돈분발효퇴비 처리구, 왕겨탄 처리구의 4 처리 3 반복으로 하였다. 본 시험에 사용된 바이오매스의 화 학적 특성은 Table 2 와 같다. 시험용 포트 설치는 시료채취 등으로 인한 토양교란을 최소화하기 위하여 각 시험구에 11 개의 원형 아크릴 무저 포트 (직경 $20 \mathrm{~cm}$, 높이 $25 \mathrm{~cm}$ )를 설치하였으며, 각각의 포트 $\left(7.85 \mathrm{~cm}^{3}\right)$ 에는 토양과 시험재

Table 1. Chemical properties of soil used at the experiment.

\begin{tabular}{|c|c|c|c|c|c|c|c|}
\hline \multirow{2}{*}{$\mathrm{pH}$} & \multirow{2}{*}{$\mathrm{EC}$} & \multirow{2}{*}{$\mathrm{OM}$} & \multirow{2}{*}{ Av. $\mathrm{P}_{2} \mathrm{O}_{5}$} & \multicolumn{3}{|c|}{ Exch. Cation } & \multirow{2}{*}{$\mathrm{CEC}$} \\
\hline & & & & K & $\mathrm{Ca}$ & $\mathrm{Mg}$ & \\
\hline$(1: 5)$ & $\mathrm{dS} \mathrm{m}^{-1}$ & $\mathrm{~g} \mathrm{~kg}^{-1}$ & $\mathrm{mg} \mathrm{kg}{ }^{-1}$ & \multicolumn{4}{|c|}{ - } \\
\hline 7.14 & 0.49 & 19.5 & 481.4 & 0.59 & 7.60 & 2.16 & 11.09 \\
\hline
\end{tabular}

Table 2. Chemical properties of biomass used in the experiment.

\begin{tabular}{|c|c|c|c|c|c|}
\hline & $\mathrm{pH}$ & $\mathrm{EC}$ & $\mathrm{C}$ & $\mathrm{N}$ & $\mathrm{C} / \mathrm{N}$ \\
\hline & $(1: 10)$ & $\mathrm{dS} \mathrm{m}^{-1}$ & --.----- & 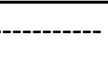 & \\
\hline ERH & 7.9 & 0.54 & 36.3 & 0.4 & 90.7 \\
\hline $\mathrm{CRH}$ & 10.2 & 0.82 & 42.7 & 0.5 & 85.4 \\
\hline PMC & 7.2 & 4.0 & 31.9 & 2.71 & 11.8 \\
\hline
\end{tabular}

${ }^{\dagger}$ ERH : Expander Rice Hull, CRH : Carbonized Rice Hull, PMC : Pig Manure Compost 
료인 바이오매스를 완전 혼합하여 충진하였다. 시험재료 처 리는 농촌진흥청 작물별 시비처방 기준 (2010)에 따라 돈분 발효퇴비는 $1 \mathrm{ha}$ 당 퇴비 15 톤 시용기준량의 $22 \%$ 해당량인 3.3톤을 처리하였다. 또한 탄화왕겨인 왕겨숯은 $1 \mathrm{ha}$ 당 5 톤, 왕겨를 팽연화 시킨 팽연왕겨는 왕겨숯과 같은 량으로 5 톤을 처리하였고, 무처리구는 대조구로 바이오매스 재료 를 처리하지 않고 수행하였다. 비료 시용은 처리된 시험재 료의 분해과정에 필요한 양분 공급을 위한 3요소 시용구와 무시용구를 두었다. 3요소 시용구는 일반적으로 밭작물의 주요 작물인 보리 표준시비량을 기준으로 $\mathrm{N}-\mathrm{P}_{2} \mathrm{O}_{5}-\mathrm{K}_{2} \mathrm{O}$ 를 각각 76-66-30 kg ha ${ }^{-1}$ 전량 밑거름으로 시용하였다.

시험기간 중 토양 온도측정은 유전율식 센서를 포트 내의 토양에 $5,10,20$, 및 $50 \mathrm{~cm}$ 깊이에 설치하였고, 토양 수분 함량은 tensiometer를 토양 표면에서 직각으로 꽂고 데이터 로거를 이용하여 자동 측정하였다. 강우량은 시험포장 인근 에 위치한 수원기상대 (위도: $37^{\circ} 16^{\prime} \mathrm{N}$, 경도: $126^{\circ} 59^{\prime} \mathrm{E}$, 해발 고도: $34.5 \mathrm{~m}$ )에서 측정되는 일별 기상자료를 이용하였다.

토양화학성은 토양시료를 채취하여 풍건 후 $2 \mathrm{~mm}$ 체를
통과시켜 농촌진흥청 토양화학분석법 (NAAS, 2010)에 준하 여 분석하였다. $\mathrm{pH}$ (1:5)는 초자전극법, 유기물은 Tyurin법, 유효인산은 Lancaster법, 치환성 양이온은 $1 \mathrm{~N} \mathrm{NH}_{4} \mathrm{OAC}(\mathrm{pH}$ 7.0)용액으로 침출하여 유도결합플라즈마방출분광기 (Optima 7300DV, Perkin Elmer)로 분석하였다. 제조된 시료의 $\mathrm{pH}$ 와 전기전도도는 $\mathrm{pH} / \mathrm{EC}$ meter (Orion 4 Star, Thermo, Singapore) 로 측정하였고, $\mathrm{NO}_{3}-\mathrm{N}$ 는 증류수로 침출하여 이온크로마토그 래피 (850 professional, Metrohm), $\mathrm{NH}_{4}-\mathrm{N}$ 는 $2 \mathrm{~mol} \mathrm{KCl}$ 로 침 출하여 자외선/가시선 분광광도계 (Cary 100, Varian)로 분석 하였다. 바이오매스 분석은 식물체 분석법에 준하여 $\mathrm{pH}(10: 1)$ 는 초자전극법, $\mathrm{EC}$ 는 조제된 시료 $10 \mathrm{~g}$ 을 $100 \mathrm{ml} 200 \mathrm{ml}$ 삼 각플라스크에 취하여 증류수 $50 \mathrm{ml}$ 를 가하고 진탕기에서 30 분 간 진탕하였다. 그리고 NO. 2 여과지로 여과 후 $\mathrm{EC}$ meter로 측 정하였다. 총탄소 $(\mathrm{T}-\mathrm{C})$ 와 총질소 $(\mathrm{T}-\mathrm{N})$ 는 원소분석기 (Vario Max CN analyzer, Elementar, Germany)로 분석을 실시하였다.

온실가스 포집은 밀폐형 상자법 (Denmead, 1979)을 이용 하였다. 설치된 챔버는 지름이 $13.3 \mathrm{~cm}$, 높이가 $30 \mathrm{~cm}$ 인 아 크릴 소재로 Fig. 1과 같이 제작하여 시험포장에 설치하고

Table 3. Gas chromatographic analysis conditions for $\mathrm{CO}_{2}$ and $\mathrm{N}_{2} \mathrm{O}$ measurement.

\begin{tabular}{|c|c|c|}
\hline $\mathrm{CO}_{2}$ & & \\
\hline Detector & & FID \\
\hline \multirow{3}{*}{ Column } & Packing material & Hayesep Q \\
\hline & Materials & Stainless steel \\
\hline & O.D. $x$ length & $1 / 8^{\prime \prime} \times 3.66 \mathrm{~m}$ \\
\hline Carrier gas & & $\mathrm{N}_{2}$ \\
\hline \multirow{2}{*}{ Flow rate } & Carrier & $23 \mathrm{ml} \mathrm{min}^{-1}$ \\
\hline & Make up & $2 \mathrm{ml} \mathrm{min} \operatorname{mon}^{-1}$ \\
\hline \multirow{2}{*}{ Temperature } & Oven & $60^{\circ} \mathrm{C}$ \\
\hline & Detector & $250^{\circ} \mathrm{C}$ \\
\hline Retention time & & $9 \min$ \\
\hline Concentration of calibration gas & & 400 and 1000 ppmv $\mathrm{CO} 2$ in N2 \\
\hline Loop & & $2 \mathrm{ml}$ \\
\hline \multicolumn{3}{|l|}{$\mathrm{N}_{2} \mathrm{O}$} \\
\hline Detector & & $\mu \mathrm{ECD}$ \\
\hline \multirow{3}{*}{ Column } & Packing material & Hayesep Q \\
\hline & Materials & UltiMetal \\
\hline & O.D. $x$ length & $1 / 8^{\prime \prime} \times 1.83 \mathrm{~m}$ \\
\hline Carrier gas & & $\mathrm{CH}_{4} 5.0 \% / \mathrm{Ar}$ \\
\hline \multirow{2}{*}{ Flow rate } & Carrier & $21 \mathrm{ml} \mathrm{min}{ }^{-1}$ \\
\hline & Make up & $2 \mathrm{ml} \min ^{-1}$ \\
\hline \multirow{2}{*}{ Temperature } & Oven & $60^{\circ} \mathrm{C}$ \\
\hline & Detector & $350^{\circ} \mathrm{C}$ \\
\hline Retention time & & $9 \min$ \\
\hline Concentration of calibration gas & & 0.5 and 1.0 ppmv $\mathrm{N}_{2} \mathrm{O}$ in $\mathrm{N}_{2}$ \\
\hline Loop & & 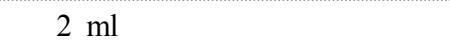 \\
\hline
\end{tabular}




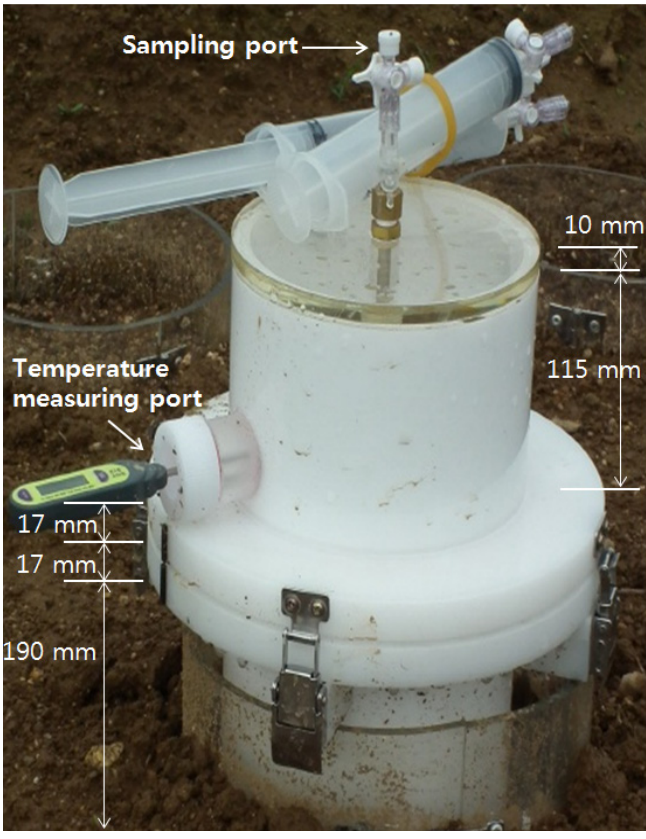

Fig. 1. Schematic model of a closed gas chamber.

외부와의 공기를 차단하여 밀폐상태로 포집하였다.

온실가스 시료채취는 Yagi (1991)의 방법에 의하여 10:0012:00 사이에 $60 \mathrm{ml}$ 실린지를 이용하여 2주일에 1회 채취하 여 분석하였다. 채취한 가스시료의 $\mathrm{CO}_{2}$ 농도 분석은 $\mathrm{GC}-\mathrm{FID}$ (Agilent 7890A)를 사용하였고, column은 Hayesep Q (80/100 mesh)를 충전한 $1 / 8^{\prime \prime} \times 3.66 \mathrm{~m}$ 의 stainless steel tubing column, 그리고 detector의 온도는 $250^{\circ} \mathrm{C}$ 로 하였다. $\mathrm{N}_{2} \mathrm{O}$ 농도 분석 은 GC- $\mu \mathrm{ECD}$ (Agilent 7890A)를 사용하였고, column은 Hayesep Q (80/100 mesh)를 충전한 $1 / 8^{\prime \prime} \times 1.83 \mathrm{~m}$ 의 ultiMetal tubing column, 그리고 detector의 온도는 $350^{\circ} \mathrm{C}$ 로 하였다. $\mathrm{CO}_{2}$ 분 석 및 $\mathrm{N}_{2} \mathrm{O}$ 분석을 위한 세부조건은 Table 3 과 같다.

단위 시간당 $\mathrm{CO}_{2}$ 와 $\mathrm{N}_{2} \mathrm{O}$ 의 배출량은 다음 식에 따라서 계 산하였다.

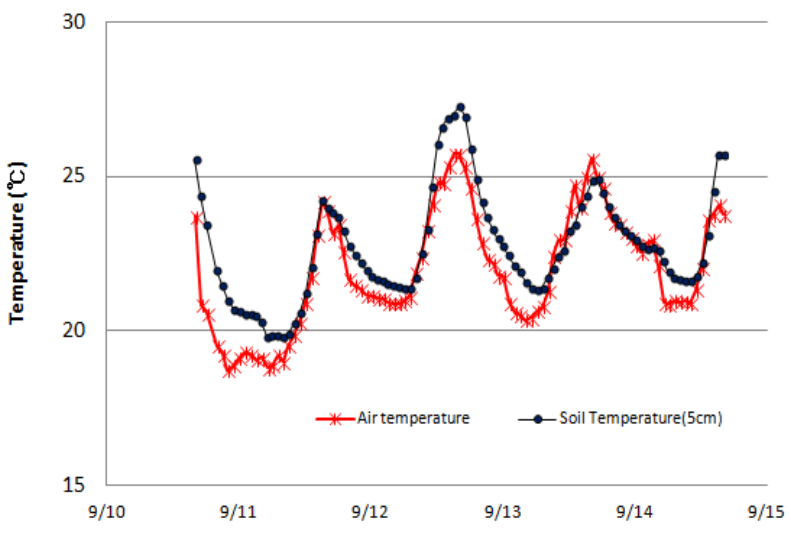

(a)

$$
\begin{aligned}
& \mathrm{F}=\rho \cdot 273 \cdot\left[273+\left(\text { 처음온도+나중온도) } \cdot 2^{-1}\right]^{-1} \cdot \mathrm{H} \cdot \Delta \mathrm{C} \mathrm{h}^{-1} 1000^{-1}\right. \\
& \mathrm{F} \text { : 단위시간당 배출량 }\left(\mathrm{mg} \mathrm{m}^{-2} \mathrm{hr}^{-1}\right) \\
& \rho \quad \text { : 가스밀도 }\left(\mathrm{mg} \mathrm{m}^{-3}\right) \\
& \mathrm{N}_{2} \mathrm{O} \text { 의 } \rho \text { 값 }(\mathrm{T}=273 \mathrm{~K}) \text { 은 다음과 같다. } \\
& \rho_{\mathrm{N} 20}=1.96, \rho_{\mathrm{N} 20-\mathrm{N}}=1.25
\end{aligned}
$$

\section{Results and Discussion}

바이오매스 처리에서 토양온도의 경시적 변화는 Fig. 2 와 같다. 토양 지표면 온도 범위는 $20-28^{\circ} \mathrm{C}$ 로 대기온도 $18-26^{\circ} \mathrm{C}$ 와 유사하였는데, 이는 토양 지표온도가 대기온도 와 밀접한 영향을 받는 것으로 판단되었다. 또한 토양 $20 \mathrm{~cm}$ 깊이에서 토양 온도는 $22-24^{\circ} \mathrm{C}$ 범위를 유지하였으나 30 $\mathrm{cm}$ 깊이에서 토양온도는 $23^{\circ} \mathrm{C}$ 정도로 조사되었다.

온도는 토양의 $\mathrm{CO}_{2}$ 생성에 중요한 요소로 작용하여 19세기 말부터 토양의 $\mathrm{CO}_{2}$ flux를 예측하는데 사용되었다 (Arrhenius, 1889, Vant't Hoff, 1898). 대기온도에 따른 토양온도 변화 는 $\mathrm{N}_{2} \mathrm{O}$ 배출량에도 영향을 미친다 (Frolking et al., 1998; Parton et al., 1996)고 하였는데, 대기온도와 토양 깊이별 토양온도 변화는 땅속 $5 \mathrm{~cm}$ 와 $10 \mathrm{~cm}$ 깊이에서는 대기온도 변화와 아주 비슷한 양상을 보였으며, $20 \mathrm{~cm}$ 깊이에서는 변 화폭이 $0.5^{\circ} \mathrm{C}$ 범위로 아주 적고 대기온도에 비해 약간 느린 속도의 변화를 보였다 (Fig. 3(b)-(d)). 그러나 땅속 $50 \mathrm{~cm}$ 깊이에서는 토양온도가 일정하게 유지되고 있어 대기 온도 변화에 따른 영향은 거의 없는 것으로 판단되었다 (Fig. 3(a)). 바이오매스 처리에 따른 토양 깊이별 온도 변화를 조 사하기 위해 같은 시간대의 온도 변화를 보면 땅속 $5 \mathrm{~cm}$ 에

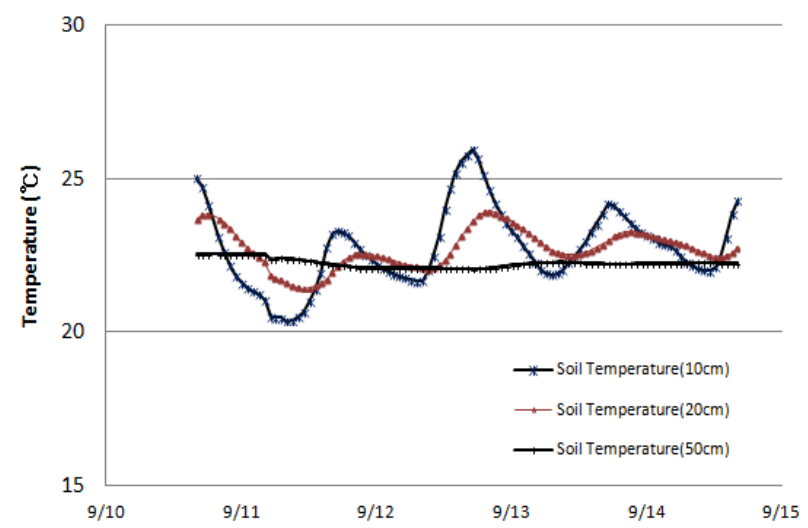

(b)

Fig. 2. Change of soil temperature with soil depths. A: Air temperature and soil temperature of top layer, B: soil temperature with different soil depths. 


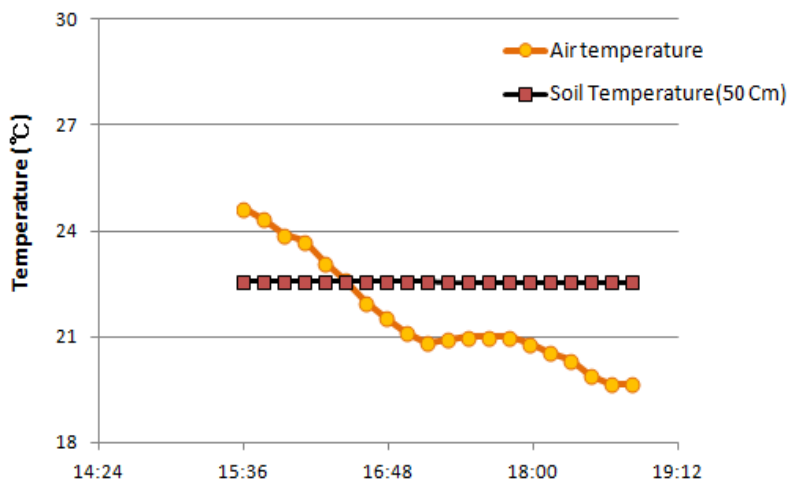

(a)

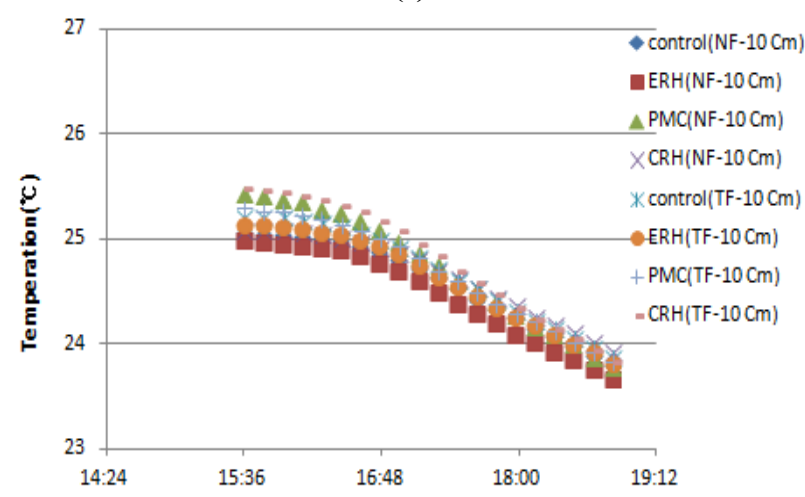

(c)

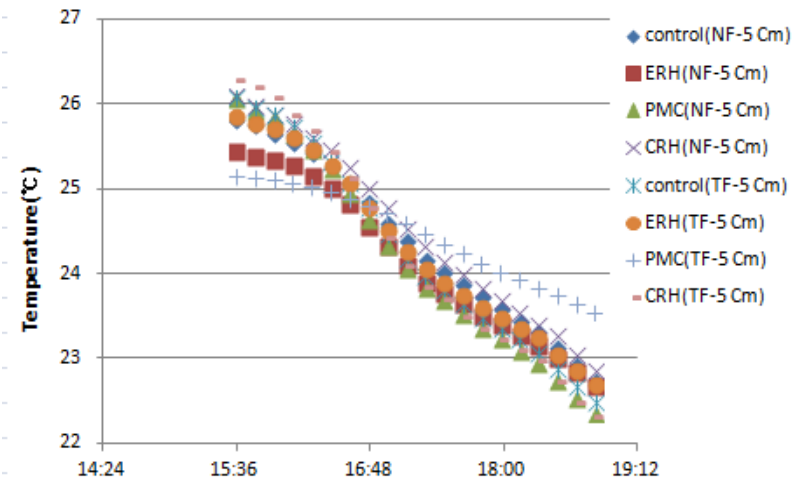

(b)

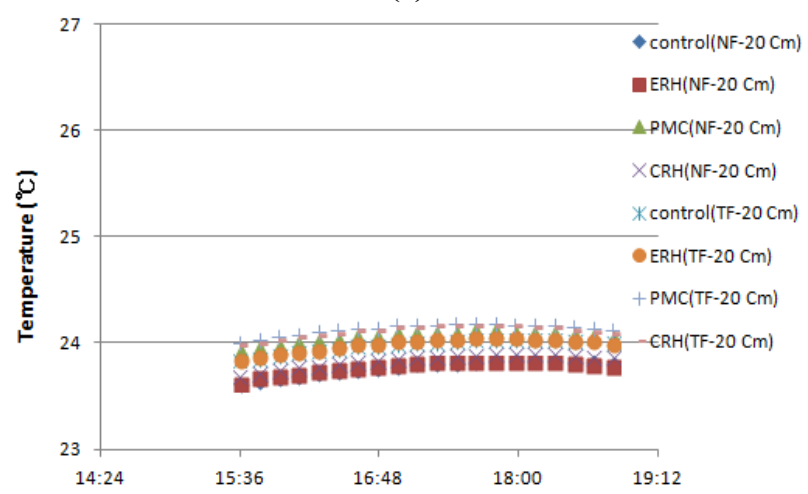

(d)

Fig. 3. Temporal change of soil temperature with depths of treated biomass. A: Air temperature and temperatures at $50 \mathrm{~cm}$ of soil depth(9/10), B : Temperatures at $5 \mathrm{~cm}$ of soil depth(9/10), C : Temperatures at $10 \mathrm{~cm}$ of soil depth(9/10), D : Temperatures at 20 cm of soil depth(9/10).

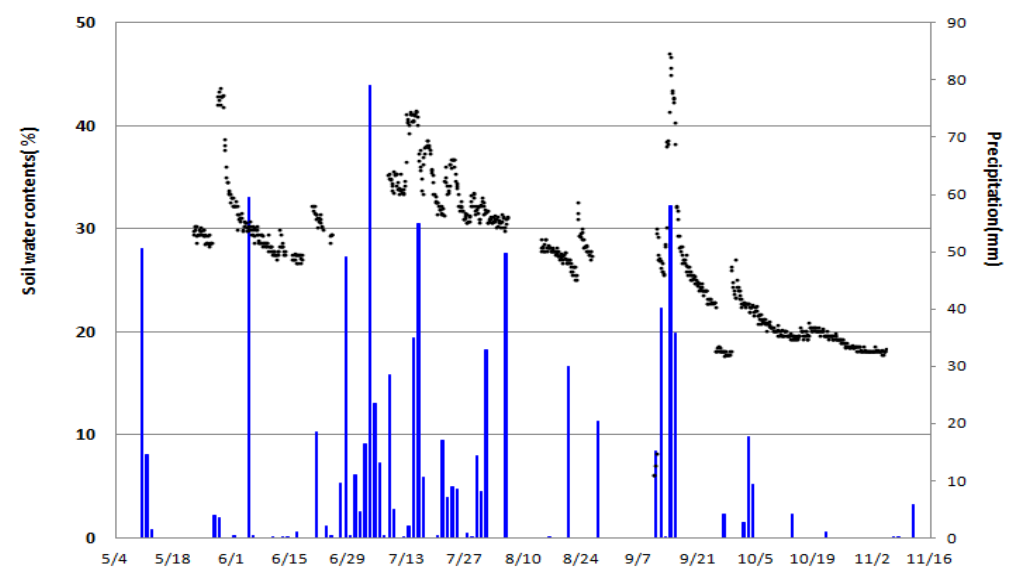

Fig. 4. Change of precipitation and soil water contents during the study period.

서는 대기온도 보다 $1-2^{\circ} \mathrm{C}$ 높게 나타났으며, 대기 온도에 따른 영향으로 판단되며, 바이오매스별 처리 간에는 유의성 있는 차이는 보이지 않았다 (Fig. 3(b)). 토양 $10 \mathrm{~cm}$ 깊이에 서는 $5 \mathrm{~cm}$ 깊이에서 보다 더 낮은 온도 값을 보였으며, 오 후 늦은 시간으로 갈수록 처리 간 온도 폭도 좁아지는 양상 을 보였다 (Fig. 3(c)). 그러나 $20 \mathrm{~cm}$ 깊이에서 온도 변화폭 은 대기 온도보다 상대적으로 온도 변화가 적은 것으로 나 타났으며 처리 간에도 일정한 온도 값을 나타내었다 (Fig. $3(d))$.
Fig. 4는 시험기간 동안의 강우량 및 토양수분 함량 변화 를 나타낸 것이다.

바이오매스 처리에 따른 토양수분 함량은 강수량에 따른 영향이 컸으나 처리구간에는 차이를 보이지 않았고, 건조한 가을철에는 대체로 낮은 경향을 보였다. Davidson (1991)는 호기조건의 건조 토양은 미생물에 의해 질산화작용이 촉진 되고, 상대적으로 습한 토양에서는 탈질현상으로 $\mathrm{N}_{2} \mathrm{O}$ 와 $\mathrm{N}_{2}$ 의 발생이 증가한다고 하였다. 또한 여러 연구결과에서 토 양수분 (Stevens et al. 1997; Arnone and Bohlen 1998; Hou 
et al. 2000)과 토양온도 (Gödde and Conrad, 1999)의 변화 에 따른 $\mathrm{N}_{2} \mathrm{O}$ 배출 양상이 비슷하다고 알려져 있다.

시험기간 동안의 바이오매스 처리별 $\mathrm{CO}_{2}$ 및 $\mathrm{N}_{2} \mathrm{O}$ 배출량 변화는 Fig. 5와 같다.

바이오매스 원료 처리에 따른 $\mathrm{CO}_{2}$ 배출량 측정은 7 월 중 순경부터 실시하였는데, NPK를 시용하지 않은 무처리구에 서는 다른 처리구에 비해 초기에는 적게 배출되었으나 후기 에는 높은 배출량을 보였다. 또한 왕겨탄 (숯) 처리구가 시 험기간 동안에는 가장 낮은 $\mathrm{CO}_{2}$ 배출량을 보였다. 그러나 $\mathrm{NPK}$ 를 시용한 처리구에서는 바이오매스 무처리구와 왕겨 탄 처리구에서 낮은 배출율을 보였다.

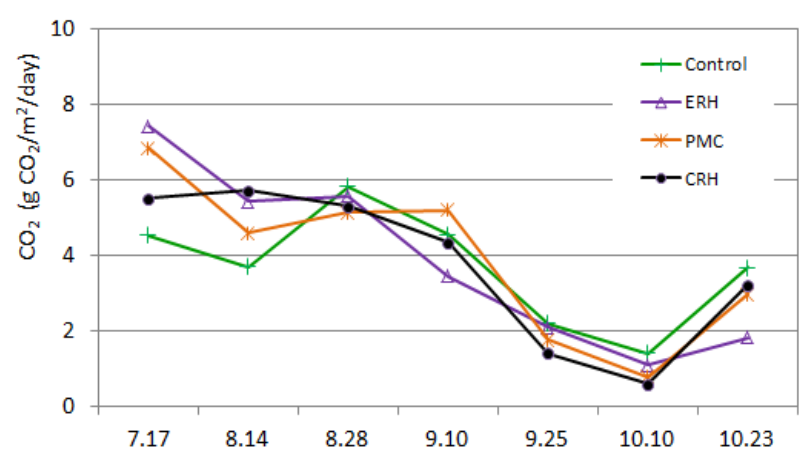

(a)
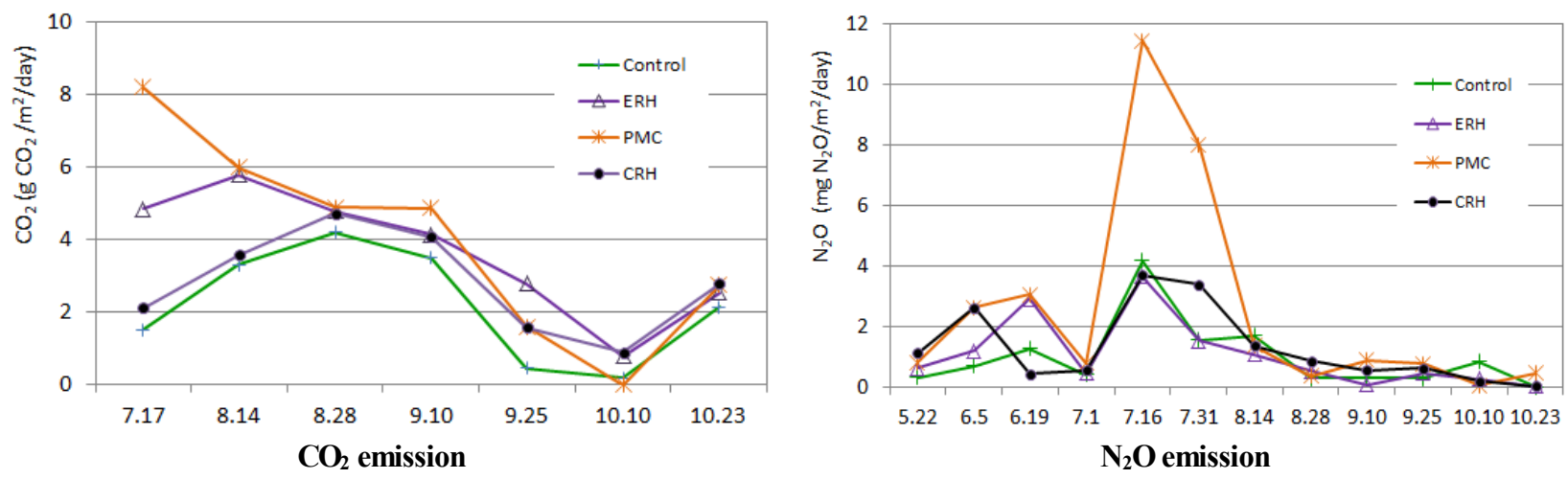

(b)

Fig. 5. Changes of $\mathrm{CO}_{2}$ and $\mathrm{N}_{2} \mathrm{O}$ emissions by different biomass in upland soils(all flux measurements included). A : NPK fertilizer none, B : NPK fertilizer applied. ERH : Expander Rice hull, PMC : Pig Manure Compost, CRH : Carbonized Rice hull.

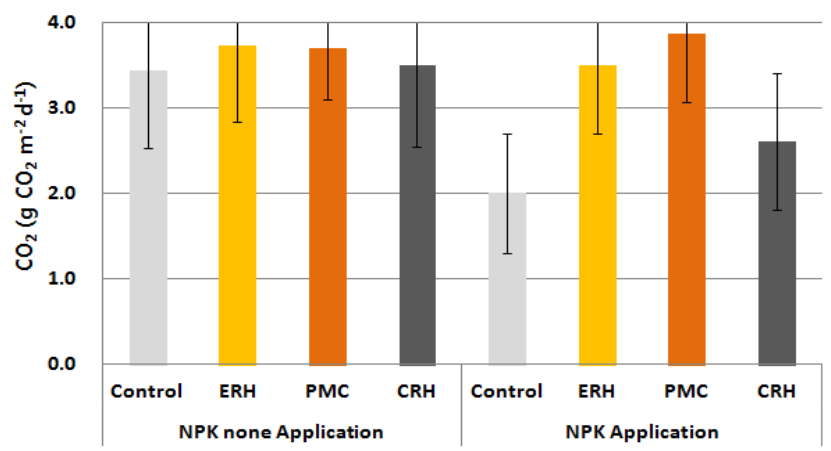

(a) $\mathrm{CO}_{2}$ emission

농경지로부터 아산화질소 배출은 토양 특성뿐만 아니라 기상 조건의 영향을 크게 받으므로, 감소 정도의 변화 폭이 크다고 볼 수 있다 (Kim et al., 2008; Kim et al., 2010; Yang et al., 2012 a; Yang et al., 2012 b).

$\mathrm{N}_{2} \mathrm{O}$ 배출량은 무처리구에서 초기에는 낮은 배출량을 보 였으나, 일시적으로 급격한 배출량을 보인 후에는 점차 감 소하는 경향이었으며, 다른 처리구와 비슷한 양상을 보였 다. 또한 왕겨탄 (숯) 처리구의 $\mathrm{N}_{2} \mathrm{O}$ 배출량도 무처리구에서 와 같이 일시적으로 약간 높은 양상을 보인 것 외에는 다른 처리구와 비슷한 양상을 보였으나, 시험기간 동안에는 가장 낮은 배출량을 보였다.

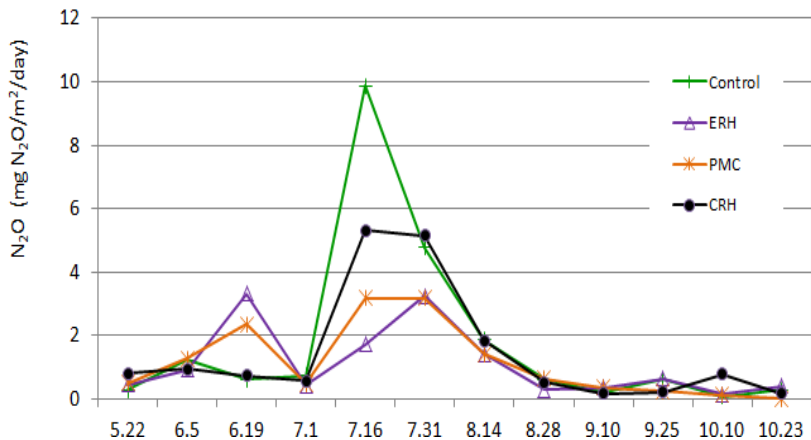


바이오매스 원료 처리와 $\mathrm{NPK}$ 시용에 따른 1 일 $\mathrm{CO}_{2}$ 배출 량은 모든 처리구에서 비슷한 배출양상을 보였으나 무처리 구가 시험기간 동안에는 가장 낮은 배출량을 보였다. 1일 $\mathrm{N}_{2} \mathrm{O}$ 배출량은 $\mathrm{NPK}$ 를 처리한 구에서 무처리구에 비해 돈분 퇴비구에서 낮은 배출량을 보였으나, NPK를 처리하지 않은 구에서는 돈분퇴비구가 가장 많은 배출량을 보였다. 바이오 매스 원료 처리에 따른 1 일 온실가스 배출량을 바이오매스 처리별, 화학비료 (NPK) 처리별로 비교한 결과는 Fig. 6과 같았다.

바이오매스 처리에 따른 온실가스 배출특성을 보면, 바 이오매스 무처리 및 왕겨탄 처리구에서의 $\mathrm{CO}_{2}$ 배출량은 $\mathrm{NPK}$ 무처리에 비해 추가 처리구에서 각각 $43.7 \%, 21.9 \%$ 감 소하였고, 돈분 퇴비구에서는 $5.4 \%$ 증가하는 경향을 보였 다. 이러한 영향은 NPK 무처리구에서 바이오매스 무처리구 와 왕겨탄 처리구 등 모든 처리구에서 $\mathrm{CO}_{2}$ 배출량이 높았던 것과는 대조를 이루는 것으로 단일조건에 의한 영향으로 보 기에는 어려움이 있다고 판단된다. 본 연구의 특성상 작물 재배에 따른 온실가스 배출에 미치는 영향을 최소화하기 위 하여 작물을 재배하지 않고 바이오매스 처리에 따른 영향을 파악코자하는 것으로 작물 재배에 따른 여러 환경 조건이 배제된 상태로 이와 관련되는 연구가 필요할 것으로 본다. 돈분퇴비 처리구에서 $\mathrm{CO}_{2}$ 배출 양상을 보면 NPK 처리가 $\mathrm{NPK}$ 무처리에서 보다 높게 배출되고 있고, 바이오매스 무 처리 및 왕겨탄 처리의 경우에는 낮게 배출되는 경향을 보 였는데, 유기물 시용에 따른 토양수분, $\mathrm{C} / \mathrm{N}$, 유기물 분해율 및 미생물 활동에 필요한 양분 공급량, 토양온도 등 다양하 고 복잡한 상호작용에 의한 영향으로 추측된다.

$\mathrm{N}_{2} \mathrm{O}$ 배출량은 $\mathrm{NPK}$ 를 처리한 구에서는 돈분퇴비구에서 증가하였으나, $\mathrm{NPK}$ 를 무처리한 구에서는 돈분퇴비구가 $54.2 \%$ 감소하는 경향을 보였다. 또한 $\mathrm{NPK}$ 를 처리하지 않은 구에 서는 처리한 구에 비해 바이오매스 무처리 $90 \%$, 팽연왕겨
$25 \%$, 왕겨탄 $21.4 \%$ 증가하는 경향을 보였다. NPK 비료 무 처리구에서는 바이오매스 무처리구에 비해 팽연왕겨, 돈분 퇴비, 왕겨탄 처리에서 $\mathrm{N}_{2} \mathrm{O}$ 배출량은 감소하는 경향이었다. 이와 관련하여 Yanai et al. (2007)은 바이오숯을 무게 비로 $10 \%$ 를 처리하였을 때 아산화질소 배출량이 줄어들었다고 보고하였으며, Zwieten et al. (2009)은 바이오숯 처리가 토 양 $\mathrm{pH}$ 를 높여 아산화질소로부터 질소 가스로 환원시키는 효소활성이 높아짐으로서 아산화질소의 배출량이 줄어들 수 있다고 하였다. 한편으로는 바이오솣 처리가 토양 통기 성을 높여줌으로서 탈질균의 활성에 영향을 미치거나, 탈질 균의 활성에 필요한 유효태 탄소의 흡착으로 아산화질소의 배출량이 줄어들 수도 있다고 하였다. Lemke et al. (1998) 은 토양 수분 함량이 높을수록 탈질이 잘 일어나지만, 토양 공극에 대한 용적수분 함량 비율이 $90 \%$ 이상에서는 아산화 질소 배출량이 급격히 낮아진다고 하였다. 그러나 팽연왕 겨, 돈분퇴비 처리구에서는 $\mathrm{CO}_{2}$ 배출 양상에서와 마찬가지 로 유기물 분해 작용과 연관되는 복잡 다양한 상호작용에 의한 영향으로 추측된다.

바이오매스 원료 처리에 따른 총질소 함량의 변화는 Fig. 7에서 보는 바와 같이 처리 간에 차이는 보이지 않았으나, 처리기간이 늘어날수록 총질소 함량이 약간씩 감소하는 경 향을 보였다.

Fig. 8은 바이오매스 원료 처리에 따른 토양 중의 질소함 량 변화를 나타낸 것이다. 토양 중 $\mathrm{NH}_{4}-\mathrm{N}$ 함량은 시험 초 기부터 높게 나타나 55 일까지 $\mathrm{NO}_{3}-\mathrm{N}$ 함량보다 상대적으로 높았고, 124 일에는 $\mathrm{NH}_{4}-\mathrm{N}$ 함량이 급격히 감소하는 경향을 보였다. 한편 $\mathrm{NO}_{3}-\mathrm{N}$ 함량은 후기까지 높은 수준을 유지하였 다. 또한 전체적으로 바이오매스 처리별 총질소 함량 경향 치는 유사하였으나 NPK 추가 처리에서 NPK 무처리 보다 약간 높은 함량을 보였다.

바이오매스 원료별 처리에 따른 토양 중 유기물 및 유효

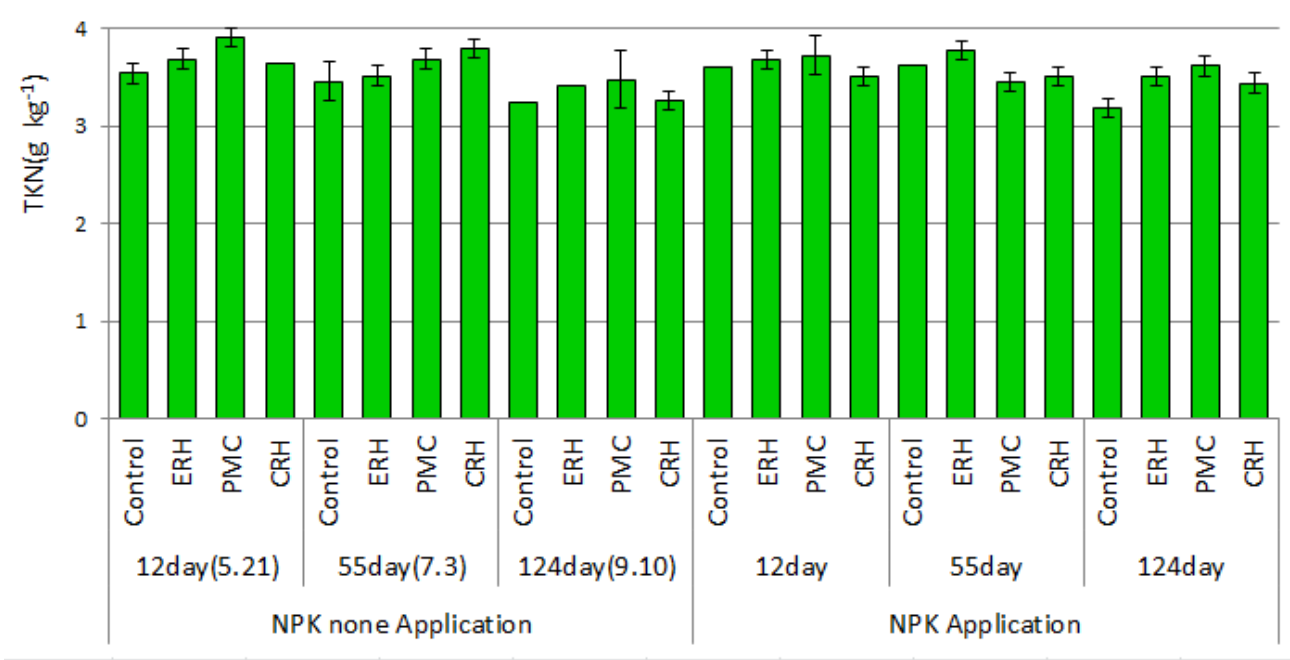

Fig. 7. Amount of total nitrogen in the soil by biomass treatments. 


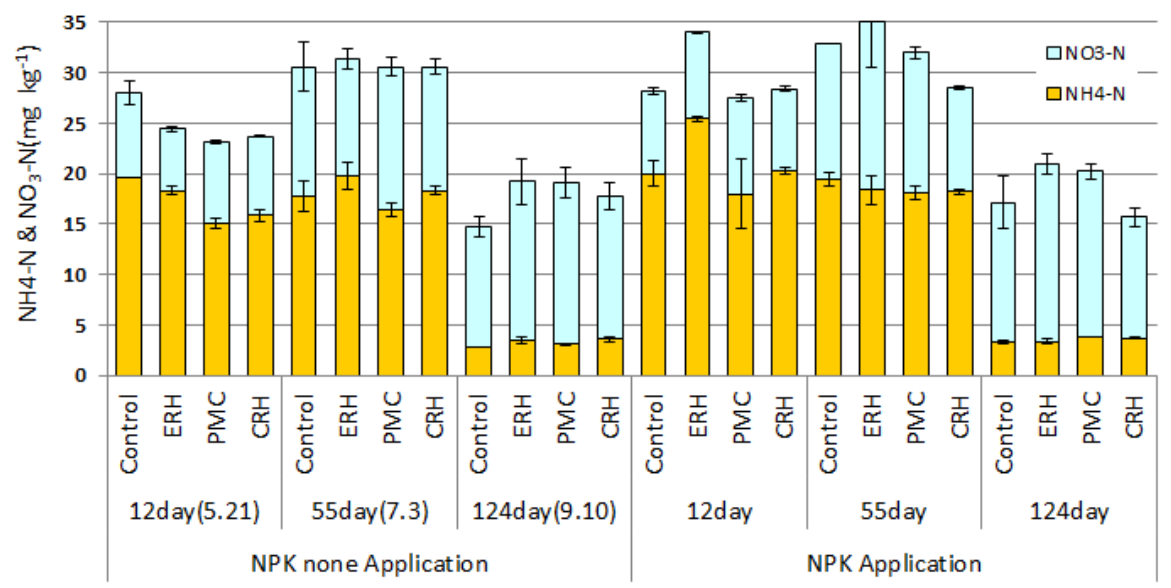

Fig. 8. Amount of $\mathrm{NH}_{4}-\mathrm{N}$ and $\mathrm{NO}_{3}-\mathrm{N}$ in the soil by biomass treatments.

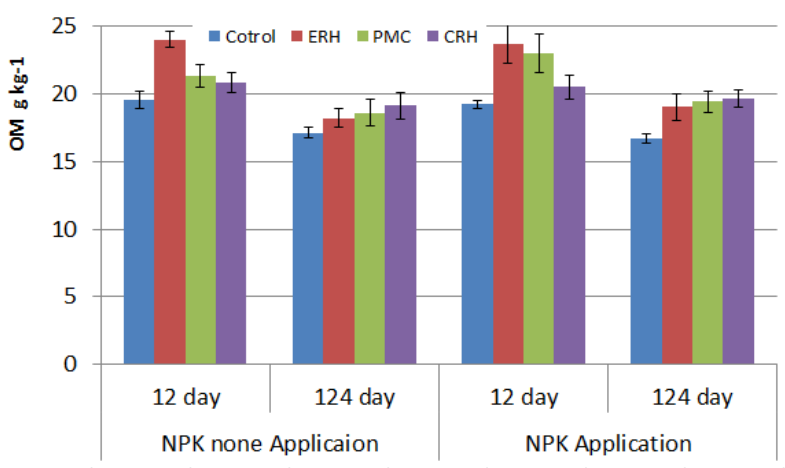

Soil organic matter content

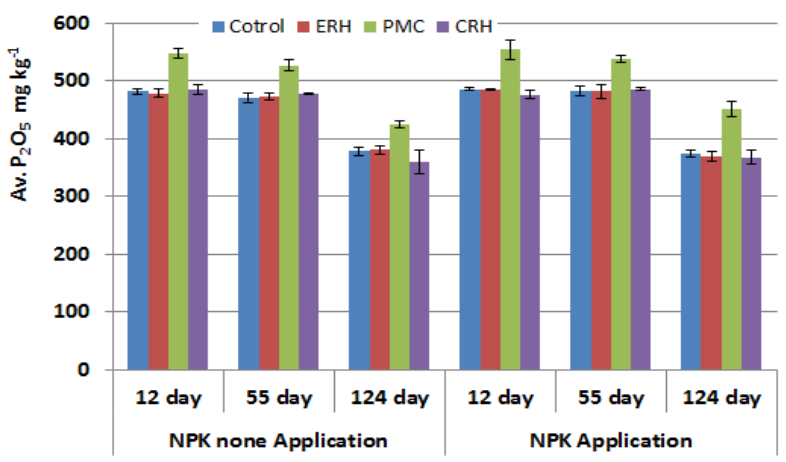

Soil available phosphorus content

Fig. 9. Amount of organic matter and available phosphorus in the soil with biomass treatments.

인산 함량은 Fig. 9와 같다. 처리 후 시간이 경과함에 따라 토양 유기물 및 유효인산 함량은 감소하는 경향을 보였고, 특히 왕겨탄 (숯) 처리구에서 토양 유기물의 감소폭이 가장 작게 나타났다.

\section{Conclusion}

농업부문의 주요 바이오매스 활용으로 인한 온실가스 배 출을 줄이고자 여러 형태의 바이오매스를 밭 포장 조건의 시험포트에 처리하여 온실가스 배출시험을 수행하였다. 또 한 시험기간 동안에 온실가스 배출에 영향을 주는 토양 중 온도 및 수분 변화와 더불어 온실가스 배출량 $\left(\mathrm{CO}_{2}, \mathrm{~N}_{2} \mathrm{O}\right)$ 을 측정하였다.

바이오매스 처리에 따른 토양온도 변화는 $5 \mathrm{~cm}$ 와 $10 \mathrm{~cm}$ 깊이의 토양에서는 대기온도와 유사한 경향치를 보였으나, 토양 깊이 $20 \mathrm{~cm}$ 에서는 대기 온도보다 상대적으로 온도 변 화가 적은 것으로 나타났다. 그러나 지중 $50 \mathrm{~cm}$ 깊이에서는 대기온도에 영향 없이 일정한 지중온도를 유지하였다. 토양 수분 함량은 강수량의 영향이 컷으며 처리구 간에는 차이를 보이지 않았고, 건조한 가을철에는 대체로 낮은 경향을 보 였다.
바이오매스 처리에 따른 토양 중 $\mathrm{NH}_{4}-\mathrm{N}$ 함량은 시험 초 기에 상대적으로 높았으나 처리 후 124 일에 급격한 감소를 보였다. 그러나 $\mathrm{NO}_{3}-\mathrm{N}$ 함량은 후기까지 높은 수준을 유지하 였다. 바이오매스 처리에 따른 온실가스 배출특성을 보면, 바이오매스 무처리 및 왕겨탄 처리구에서의 $\mathrm{CO}_{2}$ 배출량은 $\mathrm{NPK}$ 무처리에 비해 추가 처리구에서 각각 $43.7 \%, 21.9 \%$ 감 소하였고, 돈분 퇴비구에서는 $5.4 \%$ 증가하는 경향을 보였 다. 또한 $\mathrm{N}_{2} \mathrm{O}$ 배출량은 NPK 비료 무처리구에서 바이오매스 무처리 $90 \%$, 팽연왕겨 $25 \%$, 왕겨탄 $21.4 \%$ 증가하였고, 돈 분 퇴비구에서는 $54.2 \%$ 감소하는 것으로 나타나 앞으로 유 기물 토양 처리에서 유기물 분해와 온실가스 배출 영향에 대한 연구가 필요할 것으로 판단된다.

\section{References}

Arone, J.A. and P.J. Bohlen. 1998. Stimulated N2O flux from intact grassland monoliths after two growing seasons under elevated atmospheric $\mathrm{CO}_{2}$. Oecologia. 116:331-335.

Arrhenius, S. 1889. Uber die Reaktionsgeschwindigkeit bei der Inversion von ohrzucker durch Sauren. Z. Phys. Chem,. 4, 226-248. 
Davidson, E.A. 1991. Fluxes of nitrous oxide and nitric oxide from terrestrial ecosystems. In: Microbial Production and Consumption of Greenhouse Gases: Methane, Nitrous Oxide and Halomethanes (eds Rogers JE, Whitman WB), American Soc. of Microbiol., Washington, D.C. 219-235.

Denmead, O.T. 1979. Chamber systems for measuring nitrous oxide emission from soils in the field. Soil Sci. Soc. of America J. 43:89-95.

Deublein D. and A. Steinhauser. 2008. Biogas from Waste and Renewable Resources : An Introduction, WILEY-VCH Verlag GmbH \& Co. KGaA, Weinheim. ISBN 978-3-527-31841-4.

Firestone, M.K. and E.A. Davidson. 1989. Microbiological basis of $\mathrm{NO}$ and $\mathrm{N}_{2} \mathrm{O}$ production and consumption in soil. In: Andreae, M.O., Schimel, D.S. (Eds.), Exchange of Trace Gases between Terrestrial Ecosystems and the Atmosphere. Wiley, New York.

Freney, J.R. 1997. Emission of nitrous oxide form soils used for agriculture. Nutr. Cycl. Agroecosys. 49:1-6.

Frolking, S.E., A.R. Mosier, and D.S. Ojima. 1998. Comparison of $\mathrm{N}_{2} \mathrm{O}$ emissions from soils at three temperate agricultural sites: simulations of year-round measurements by four models. Nutrient Cycling in Agroecosystems. 52:77-105.

Gödde, M. and R. Conrad. 1999. Immediate and adaptational temperature effects on nitric oxide production and nitrous oxide release from nitrification and denitrification in two soils. Biol. Fertil. Soils. 30:33-40.

Gu, J., X. Zheng, and W. Zhang. 2009. Background nitrous oxide emissions from croplands in China in the year 2000. Plant Soil. 320:307-320.

Hou, A., H. Akiyama, Y. Nakajima, S. Sudo, and H. Tsuruta. 2000. Effects of urea form and soil moisture on $\mathrm{N}_{2} \mathrm{O}$ and $\mathrm{NO}$ emissions from Japanese Andosols. Chemosphere - Global Change Science. 2:321-327.

IPCC (Intergovernmental Panel on Climate Change). 2007. Contribution of Working Groups I, II and III to the Fourth Assessment Report of the Intergovernmental Panel on Climate Change, Geneva, Switzerland, pp. 104.

Keren, J.S. and M.G. Johnson. 1993. Conservation tillage impacts on national soil and atmospheric carbon levels. SCI. Soc. Amer. J. 57: 200-210.

Kim, G.Y., B.H. Song, K.A. Roh, S.Y. Hong, B.G. Ko, K.M. Shim, and K.H. So. 2008. Evaluation of greenhouse gases emissions according to changes of soil water content, soil temperature and mineral $\mathrm{N}$ with different soil texture in pepper cultivation. Korean J. Soil Sci. Fert. 41:399-407.

Kim, G.Y., K.H. So, H.C. Jeong, K.M. Shim, S.B. Lee, and D.B. Lee. 2010. Assessment of greenhouse gases emissions using global warming potential in upland soil during pepper cultivation. Korean J. Soil Sci. Fert. 43:886-891.

Lemke, R.L., R.C. Izaurralde, S.S. Malhi, M.A. Arshad, and M. Nyborg. 1998. Nitrous oxide emissions from agricultural soils of the Boreal and Parkland regions of Alberta. Soil Sci. Soc.
Am. J. 62: 1096-1102.

NAAS (National Academy of Agricultural Science). 2010. Methods of Soil Chemical Analysis. Sam-Mi press, 20-214.

Park, W.K., N.B. Park, J.D. Shin, S.G. Hong, and S.I. Kwon. 2011. Estimation of Biomass resource conversion factor and potential production in agricultura sector, Korean J Environ Agric. 30(3):252-260.

Parton, W.J., A.R. Mosier, D.O. Ojima, D.W. Valentine, D.S. Schimel, K. Weier, and A.E. Kulmala. 1996. Generalized model for $\mathrm{N}_{2}$ and $\mathrm{N}_{2} \mathrm{O}$ production from nitrification and denitrification. Global Biochem. Cycles. 10:401-412.

RDA. 2010. Fertilizer recommendation standards for various crops. Sanglok-sa. 24-28 (In Korean).

Scheutz, C. and P. Kjeldsen. 2004. Environmental factors influencing attenuation of menthane and hydrochlorofluorocarbons in landfill cover soils. Journal of Environmental Quality 33: 72-79.

Singh, S.N. and L. Tyagi. 2009. Nitrous oxide: Sources, sinks and mitigation strategies. In Sheldon A. I., Barnhart E. P. (eds.): Nitrous oxide emissions research progress. Nova Science Publishers, Inc., New York, p. 127-150.

Stehfest, E. 2008. Modelling of Global Crop Production and Resulting $\mathrm{N}_{2} \mathrm{O}$ Emissions. VDM Verlag Dr. Müller, Saarbrüken, Germany.

Stevens, R.J., R.J. Laughlin, L.C. Burns, J.R.M. Arah, and R.C. Hood. 1997. Measuring the contributions of nitrification and denitrification to the flux of nitrous oxide from soil. Soil. Biol. Biochem. 29:139-151.

Vant't Hoff, J. H. 1898. Lectures on theoretical and physical chemistry, Part 1. Chemical dynamics. Edward Arnold, London, UK., 227.

Yagi, K. 1991. Emission of biogenic gas compounds from soil ecosystem and effect of global environment. 2. Methane emission from paddy fields. Soil and Fert. Japan. 62(5): 556-562.

Yanai, Y., K. Toyota, and M. Lkazaki. 2007. Effect of charcoal addition on $\mathrm{N}_{2} \mathrm{O}$ emissions from soil resulting from resetting air-dried soil in short-term laboratory experiments. Soil Sci. Plant Nutri. 53:181-188.

Yang, S.H., H.J. Kang, S.C. Lee, H.J. Oh, and G.Y. Kim. 2012a. Influence of $\mathrm{N}$ fertilization level, rainfall, and temperature on the emission of $\mathrm{N}_{2} \mathrm{O}$ in the Jeju black volcanic ash soil with soybean cultivation. Korean J. Soil Sci. Fert. 45:451-458.

Yang, S.H., H.J. Kang, S.C. Lee, H.J. Oh, and G.Y. Kim. 2012 b. Influence of $\mathrm{N}$ fertilization level, rainfall, and temperature on the emission of $\mathrm{N}_{2} \mathrm{O}$ in the Jeju black volcanic ash soil with carrot cultivation. Korean J. Soil Sci. Fert. 45:459-465.

Zwieten, L.V., B. Singh, S. Joseph, S. Kimber, A. Cowie, and K.Y. Chan. 2009. Biochar and emissions of non- $\mathrm{CO}_{2}$ greenhouse gases from soil. In Lehmann, J. and Joseph, S. (eds.): Biochar for Environmental Management. Earthscan, London, UK. p. 227-249. 